\title{
Impacts of Nickel Laterite Post-Mining Activities on The Level of Heavy Metal Contamination in River Sediments
}

\author{
La Ode Ngkoimani \\ Universitas Halu Oleo \\ Makassar, Indonesia
}

\author{
Muh. Chaerul \\ Universitas Halu Oleo \\ Makassar, Indonesia
}

\begin{abstract}
This study aims to analyze the impact of nickel postmining activities on the heavy metal level in sediments of the river of Lambuluo, Motui Subdistrict, North Konawe District, Southeast Sulawesi province about the importance of the river biota. Then, all of the results of the sample were analyzed by dendrograms method. It was found that all of the heavy metal in the river sediment remained under control or Non-Polluted. According to this output, it can be shown that the dominant heavy metal content was Iron with minimum \& maximum value, mean, and standard deviation respectively were $1.0733,1.1067,1.087783$ and 0.0150264 . All of the heavy metals in the sediment in settling pond caused Heavy pollution and High Effect ranges, except Chromium VI. Based on this output, it can be shown the dominant heavy metal content was Iron with a minimum \& maximum value, mean, and standard deviation respectively were 13500, 217000, 193000, and 22172.88.
\end{abstract}

\section{Keywords—nickel laterite; heavy metal; river sediments}

\section{INTRODUCTION}

Nickel mining activities cause heavy metal contamination in coastal waters, and at high levels can lead to pollution, which will have a negative impact on aquatic biota. According to Rainbouw, the metal at low levels required the organism, but at high levels can be toxic and disrupt health [1]. According to Paquin et al., heavy metal waste due to industrial activity may cause contamination of heavy metals in coastal or river waters [2].

This nickel mining activity causes heavy metal contamination in coastal waters, and if it occurs at high levels, it can cause pollution, which will have an adverse impact on aquatic biota. Also, nickel mining activities through rivers and other bodies of water carry a lot of waste containing various toxic contaminants into the river. Contaminants include heavy metals $\mathrm{Pb}, \mathrm{Cd}, \mathrm{Cr}, \mathrm{Fe}, \mathrm{Cu}, \mathrm{Zn}$, and $\mathrm{Ni}$. Although it is known that the presence of heavy metals in water is a limited number of certain natural behaviors in pools of water, sediment, and fatty biota. But the presence of heavy metals will increase in case of industrial waste increases as well as other activities [3].

It was reported that heavy metal contamination in coastal and estuary waters in Tianjin Bohai Bay of China due to various activities on land and marine waters [4], [5]. Heavy metals can also be derived from industrial activities, agriculture, urban and mining [6], [7]. Heavy metals that accumulate in the waters can infect humans through water or fish consumption, in addition to which metals exceeding the threshold value may be toxic [8]. The higher levels of metal content in water will affect the ecological balance by changing the various organisms that live in water [9]. Concerning morphological and hydrological conditions, solutes such as metals can accumulate along the waters, and even after passing several kilometers from pollution sources [10].

One of the areas that have a lot of nickel laterite deposit and nickel mine in Southeast Sulawesi Province is Motui District, North Konawe Regency. This nickel mining is located in Motui District, namely Mount Lamotia with an area of drilled 439,5 Ha. By Production Business License (IUP), this mining began to be managed since 2007 and entered the stage of exploitation in 2010 until now.

The Lambuluo River, which is located in the mine, is a mine waste disposal site. It is identified that the waters of the river are turbidity, especially during heavy rains, then the river water changes color to redness. It is due to the land derived from mining activities carried by rainwater into the river. This situation has estimated the accumulation of metals in the river. Heavy metals that enter the river will be passed to the wider waters, and if in large quantities it is hazardous to the health of consuming products from the waters [11]. Therefore, this study aims to analyze the impact of nickel mining activities on heavy metal contamination rates for $\mathrm{Cr}^{6+}, \mathrm{Fe}^{3+}, \mathrm{Ni}^{2+}$, and pollution on sediments in the Lambuluo River, Motui District, Konawe Utara District, Southeast Sulawesi Province, Indonesia.

\section{RESEARCH METHOD}

The study was located in the River of Lambuluo, Motui Sub-District, North Konawe District, Southeast Sulawesi Province. Samples were taken from three points, which were at the output, in the middle, and at the input of the river, namely sediment samples (Figure 1). 


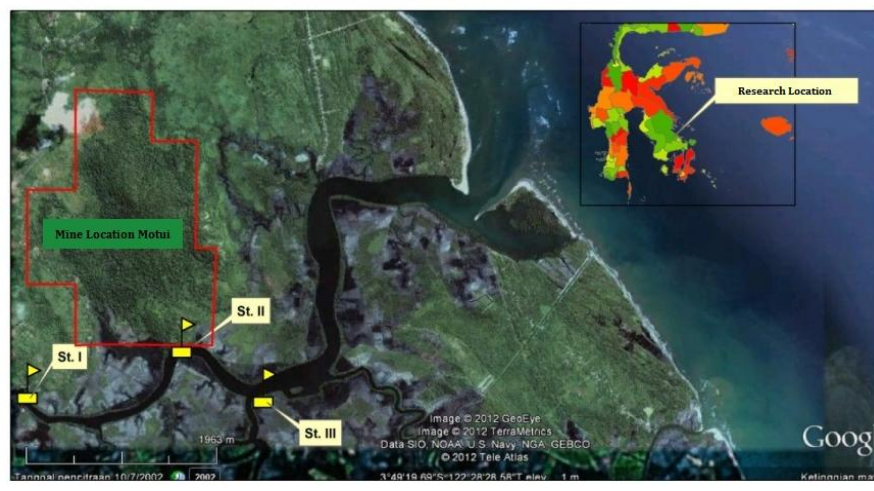

Fig. 1. Location map and points of water sampling station

Sediment samples in this study were taken at each research station. Each sample is repeated 3 (three) times. For three days at intervals between the first, second and third day taking days.

The tools used in this research are: Geological Compass, sample pouch, Polarisation Microscope, Hitachi Z-2000 Atomic Absorption Spectrophotometer (AAS), glass cup, measuring cup, funnel, balance sheet analytical, plastic bottles, sample bottles, volume pipettes, gegeps, shelves, stirrer bars, plastic spoons, water samplers and pumpkins. To measure environmental parameters using Turbidimeter, $\mathrm{pH}$ meter, thermometer, TSS meter, hollow cathode lamp (As, $\mathrm{Cd}, \mathrm{Cr}^{6+}$, $\mathrm{Ni}$ and $\mathrm{Fe}$ ).

The materials used were sediment samples, concentrated HNOUI solution, standard solution Cd $1000 \mathrm{mg} / \mathrm{L}\left(\mathrm{Cd}_{2} \mathrm{SO}_{4}\right)$, standard solution of $\mathrm{Ni} 1000 \mathrm{mg} / \mathrm{L}\left(\mathrm{NiSO}_{4}\right)$, standard solution As $1000 \mathrm{mg} / \mathrm{L}\left(\mathrm{As}_{2} \mathrm{O}_{3}\right)$, standard solution $\mathrm{Cr}^{6+} 1000 \mathrm{mg} / \mathrm{L}$ (Chromium Oxide) and standard solution of Fe $1000 \mathrm{mg} / \mathrm{L}$ $\left(\mathrm{FeCl}_{3} \cdot 6 \mathrm{H}_{2} \mathrm{O}\right)$, Whatman filter paper $40(0.42 \mu \mathrm{m})$, and aquabides.

Sediment sampling was conducted randomly at each station. The sampling point is Station control area (upstream river area), Station river flow Around the mining area, and Station: river flow after mine area (river mouth). Then the whole observation samples were analyzed by the dendrogram method.

\section{RESULTS}

The level of heavy metal pollution in river sediments was observed using metal parameters $(\mathrm{mg} / \mathrm{l})$, namely: Chromium VI $\left(\mathrm{Cr}^{6+}\right)$, Nickel $\left(\mathrm{Ni}^{2+}\right)$ and Iron $\left(\mathrm{Fe}^{3+}\right)$. Also, standard of Sediment quality is provided in the following (Table 1).

Table 2, show that the content of; (1) Chromium VI $\left(\mathrm{Cr}^{6+}\right)$ in the river sediments was produced at 0.0020 to 0.0028 with a mean and standard deviation respectively by 0.0025 and 0.0003578. Thus, the presence of Chromium VI $\left(\mathrm{Cr}^{6+}\right)$ in the river sediments was concluded as Non-Polluted, (2) Nickel $\left(\mathrm{Ni}^{2+}\right)$ in the river sediments was obtained at 0.1969 to 0.4312 with a mean and standard deviation respectively by 0.3526 and 0.0969824 . Thus, the presence of nickel $\left(\mathrm{Ni}^{2+}\right)$ in the river sediments was concluded as Non-Polluted, (3) Iron $\left(\mathrm{Fe}^{3+}\right)$ in river sediments was obtained by 1.0733 to 1.1067 with a mean and standard deviation respectively by 1.087783 and 0.0150264

TABLE I. QUALITY STANDARD SEDIMENT MATERIAL (US EPA, 2003)

\begin{tabular}{|c|c|c|c|c|}
\hline \multicolumn{5}{|c|}{$\begin{array}{c}\text { Comparison average concentration heavy metals } \\
\text { obtained in this research } \\
\text { with sediment quality guidelines }\end{array}$} \\
\hline \multirow{2}{*}{$\begin{array}{c}\text { Sediment Quality } \\
\text { Standard }\end{array}$} & \multicolumn{4}{|c|}{ Elements } \\
\hline & $C d$ & $N i$ & As & $\mathrm{Cr}$ \\
\hline \multicolumn{5}{|c|}{ CBSOG SQG*(2003) } \\
\hline Non-Polluted & $<0.99$ & $<23$ & $<9.8$ & $<43$ \\
\hline $\begin{array}{l}\text { Moderately } \\
\text { Polluted }\end{array}$ & $0.99-3$ & $23-36$ & $9.8-21.4$ & $43-76$ \\
\hline $\begin{array}{l}\text { Heavily } \\
\text { Polluted }\end{array}$ & $>3$ & $>36$ & $>21.4$ & $>76$ \\
\hline \multicolumn{5}{|c|}{ Sediment Quality Criteria Guidelines **(1992) } \\
\hline $\begin{array}{l}\text { Lowest Effect Ranges } \\
\text { (ISQG-low) }\end{array}$ & 0.6 & 16 & 6 & 26 \\
\hline $\begin{array}{l}\text { High Effect } \\
\text { Ranges } \\
\text { (ISQG-high) }\end{array}$ & 10 & 75 & 33 & 110 \\
\hline
\end{tabular}

Based on the observation result, it was obtained Descriptive Statistics from heavy metal content in river sediments (Table 2).

TABLE II. RESUlts of PRIMARY DATA PROCESSING OF SEDIMENT MATERIAL IN THE RIVER (2016)

\begin{tabular}{|l|l|l|l|}
\hline \multicolumn{1}{|c|}{ Statistic } & \multicolumn{1}{|c|}{$\begin{array}{c}\text { Chromium VI } \\
\left(\mathbf{C r}^{\mathbf{6}}\right)\end{array}$} & Nickel $\left(\mathbf{N i}^{\mathbf{2 +}}\right)$ & Ferro $\left(\mathbf{F e}^{\mathbf{3 +}}\right)$ \\
\hline Minimal & 0,0020 & 0,1969 & 1,0733 \\
\hline Maxsimum & 0,0028 & 0,4312 & 1,1067 \\
\hline Mean & 0,0025 & 0,3526 & 1,087783 \\
\hline Deviasi Standard & 0,0003578 & 0,0969824 & 0,0150264 \\
\hline Skewness & $-0,825$ & $-1,077$ & 0,758 \\
\hline Kurtosis & $-1,721$ & $-0,591$ & $-1,866$ \\
\hline
\end{tabular}

While the level of heavy metal contamination in river sediments can be seen in the following diagram (Figure 2):

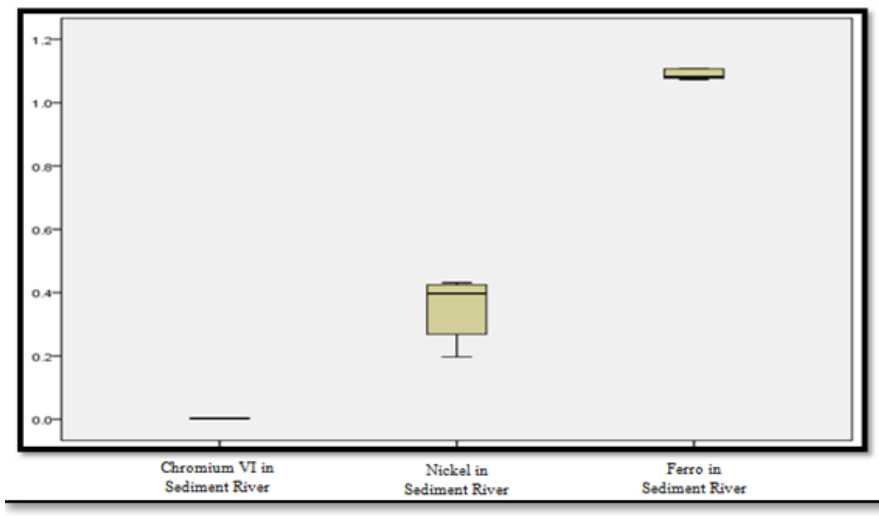

Fig. 2. Box plot diagram of Heavy Metals Contamination in River Sediment 
It can be seen that all heavy metals in river deposits remain under control or uncontaminated. Espericueta et al. suggest those trace elements tend to be concentrated in sediments with finer grain surfaces and in organic matter [12]. Wangersky reported trace elements in organic-rich sediments, due to the interaction between functional groups of organic and metal [13]. Huong in his research in Vietnam, reported a positive correlation between metal $\mathrm{Pb}, \mathrm{Cu}$, and $\mathrm{Ni}$ with organic matter content [14]. Fukue et al. state that the high metal content in the sediments has something to do with the content of organic matter produced by humus [15].

Based on this output, it can be shown that the dominant heavy metal content was Iron $\left(\mathrm{Fe}^{3+}\right)$ with a minimum \& maximum value, mean, and standard deviation respectively were $1.0733,1.1067,1.087783$ and 0.0150264 . The lines in the graphics of Whisker \& Plot showed the middle value or median. The standard quality of iron content in the sediment has not been yet established. The study mentioned that the reduction of $\mathrm{Cr}^{6+}$ occurred in anoxic and oxygen basin, in which $\mathrm{Cr}$ release will increase the content of $\mathrm{Cr}^{3+}$ in sediment because it was absorbed. Chromium contained in the sediment can be remobilized into the pores of the surrounding water by $\mathrm{Cr}^{3+}$ oxidation [16].

\section{CONCLUSION}

$\mathrm{Cr}^{6+}, \mathrm{Ni}^{2+}$, and $\mathrm{Fe}^{3+}$ heavy metals in river sediments remained under control or non-polluted. $\mathrm{Cr}^{6+}$ sediment was categorized as non-polluted, while $\mathrm{Ni}^{2+}$ and $\mathrm{Fe}^{3+}$ were included in heavily polluted and high effect ranges.

\section{REFERENCES}

[1] P. S. Rainbow, "Trace metal bioaccumulation: models, metabolic availability and toxicity," Environ. Int., vol. 33, no. 4, pp. 576-582, 2007.

[2] P. R. Paquin, K. Farley, R. C. Santore, C. D. Kavvadas, K. G. Mooney, R. P. Winfileld, K. B. Wu, and D. M. DiToro, "Metals in aquatic systems: a review of exposure, bioaccumulation, and toxicity models. Metals and the environment series," Soc. Environ. Toxicol. Chem. Press. Pensacola, FL, 2003.

[3] C. Lin, M. He, Y. Zhou, W. Guo, and Z. Yang, "Distribution and contamination assessment of heavy metals in sediment of the Second Songhua River, China," Environ. Monit. Assess., vol. 137, no. 1, pp. 329-342, 2008.

[4] M. Wei, Q. Yanwen, B. ZHENG, and L. ZHANG, "Heavy metal pollution in Tianjin Bohai bay, China," J. Environ. Sci., vol. 20, no. 7, pp. 814-819, 2008.

[5] Y. W. Qin, W. Meng, B. H. Zheng, L. Zhang, and Y. B. Su, "Contaminative features of heavy metals for tidal sediment cores in Tianjin Bohai Bay," Huan jing ke xue= Huanjing kexue, vol. 27, no. 2, pp. 268-273, 2006.

[6] J. O. Duruibe, M. O. C. Ogwuegbu, and J. N. Egwurugwu, "Heavy metal pollution and human biotoxic effects," Int. J. Phys. Sci., vol. 2, no. 5, pp. 112-118, 2007.

[7] A. Das, B. Mandal, J. Sarkar, and S. Chaudhuri, "Bioaccumulation of heavy metals in some commercial fishes and crabs of the Gulf of Cambay, India," 2007.

[8] A. Malik, "Metal bioremediation through growing cells," Environ. Int., vol. 30, no. 2, pp. 261-278, 2004.

[9] B. Y. Kamaruzzaman, Z. Rina, B. A. John, and K. C. A. Jalal, "Heavy metal accumulation in commercially important fishes of South West Malaysian coast," Res. J. Environ. Sci., vol. 5, no. 6, p. 595, 2011.
[10] K. Obolewski and K. Glińska-Lewczuk, "Contents of heavy metals in bottom sediments of oxbow lakes and the Słupia River," Pol. J. Environ. Stud, vol. 15, pp. 440-444, 2006.

[11] N. Elyazar, M. S. Mahendra, and I. N. Wardi, "Dampak aktivitas masyarakat terhadap tingkat pencemaran air laut di Pantai Kuta Kabupaten Badung serta upaya pelestarian lingkungan," Ecotrophic J. Environ. Sci., vol. 2, no. 1, 2015.

[12] X. Yang, B. Xiong, and M. Yang, "Relationships among Heavy Metals and Organic Matter in Sediment Cores from Lake Nanhu, an Urban Lake in Wuhan, China," J. Freshw. Ecol., vol. 25, no. 2, pp. 243-249, 2010.

[13] C. N. Mulligan and R. N. Yong, "Overview of natural attenuation of sediments," in Contaminated Sediments: Evaluation and Remediation Techniques, ASTM International, 2006.

[14] N. T. H. I. L. A. N. HUONG, M. OHTSUBO, L. LI, T. HIGASHI, M. KANAYAMA, and A. NAKANO, "Heavy metal contamination of soil and rice in wastewater-irrigated paddy field in a suburban area of Hanoi, Vietnam," Clay Sci., vol. 13, no. 6, pp. 205-215, 2008.

[15] M. Fukue, Y. Sato, K. Uehara, Y. Kato, and Y. Furukawa, "Contamination of sediments and proposed containment technique in a wood pool in Shimizu, Japan,” J. ASTM Int., vol. 3, no. 7, pp. 1-12, 2006.

[16] A. Bielicka, I. Bojanowska, and A. Wisniewski, "Two Faces of Chromium- Pollutant and Bioelement," Polish J. Environ. Stud., vol. 14, no. 1, pp. 5-10, 2005. 